\title{
数種殺虫剤の鹿児島県加治木地区産イエバエに 対する効力評価
}

\author{
Studies on laboratory evaluation of several insecticides \\ against two colonies of housefly from Kajiki, \\ Kagoshima Prefecture
}
大串晃 治* 徳 満 敫* 岩田登美子*
Kōji Ōgushi, Iwao Tokumitsu and Tomiko Iwata

\section{まえがき}

イエバエに対する殺虫剤の効力を評価するにはいくつ かの方法がある．各試験方法による評価はそれぞれ特長 があり，また意義がある。一般に効力は害虫と殺虫剤お よびこれらを相遇させる場の各々がもつている複雑な条 件によって発揮され，評価される．著者らは，今回フィ ールド採集のイエバエを用いて実験室内で，各試験法に よる各殺虫剤の効力評価を行ない，それぞれの特長およ び実用性を検討したので, 以下にこれらの結果を報告す る.

\section{供試昆虫}

供試したイエバエ Musca domestica vicina Macquart は 1966 年 11 月に鹿児島県加治木町中福良部落㐨よび上 木田部落で採集されたもの（以下，中福良系および上木 田系と仮称）で，以後当研究部で累代飼育し，実験には $3 \sim 4$ 世代目の健全な成虫を用いた. 中福良地区は 1966 年に鹿児島県の八工駆除パイロット地区として指定され た農家部落である，上木田地区は中福良地区と網掛川を へだてた農家部落である。これらのイエバエは成虫期は 砂糖 $5 \%$ 脱脂粉乳 $5 \%$ 水溶液で, 幼虫期はフスマ培基で 飼育し，供試イエバエは $5 \%$ 砂糖水を与えて飼育した羽 化後 $3 \sim 4$ 日令の成虫を用いた.

\section{供試薬刘}

微量滴下法抽よび滤紙面残渣接触法による実験につい ては，次に示した 11 種の各殺虫剤のアセトン溶液を用 いた。 なお薬量は純度より換算して表示した。 dichlorvos, naled, diazinon, fenchlorphos, fenthion,

* 近藤化学工業株式会社

Kondo Chem. Ind. Co., Ltd. fenitrothion, trichlorphon, malathion, dieldrin, lindane, DDT.

抵抗性簡易測定法, 直接噴霧法および浸漬法による実 験には, 次に示した各殺虫剤乳剤の所要濃度稀釈液を用 いた. これらの殺虫剤乳剤は各殺虫剤原体に xylene お よび乳化戍 $5 \%$ 量を配合して調製したものである.

dichlorvos $5 \%$ e.c., naled $5 \%$ e.c., diazinon $5 \%$ e. c., fenchlorphos $5 \%$ e.c., fenthion $5 \%$ e.c., fenitrothion $10 \%$ e.c., trichlorphon $10 \%$ e.c., malathion $20 \%$ e.c., dieldrin $5 \%$ e.c., lindane $10 \%$ e.c., DDT $30 \%$ e.c.

\section{実験方法}

\section{1. 微量滴下法}

麻酔したイエバエ雌成虫の胸背部に各殺虫剂のアセト ン溶液を $0.76 \mu \mathrm{l}$ 宛滴下し, $5 \%$ 砂糖水を与えて $25^{\circ} \mathrm{C}$ で 24 時間飼育後の致死数を求めた。 なお実験江各薬量 について 25 頭を用い 2 回繰返し平均值を求めた.

\section{2. 濾紙面残渣接触法}

各殺虫剂のアセトン溶液を濾紙面に $250 \mathrm{mg} / \mathrm{m}^{2}$ の割 合 (DDT だけは $\left.2500 \mathrm{mg} / \mathrm{m}^{2}\right)$ で散布し，アセトンを揮 発させたのち直ちに, および室内 $\left(\right.$ 最高 $27^{\circ} \mathrm{C}$ 最低 $11^{\circ} \mathrm{C}$ の室温）に 5，10，15，20 日間放置したのち径 $9 \mathrm{~cm}$ 高 さ $2 \mathrm{~cm}$ のシャーレに入れたイエバエ雌成虫 25 頭を接 触させ時間の経過にともならノックダウン数, 所定の各 時間だけ 接触させた場合の 24 時間後の 致死数および 2 時間接触したのち， $5 \%$ 砂糖水を与えて $25^{\circ} \mathrm{C}$ で飼育し 24 時間後の致死数を求めた。 な㧍接触は $25^{\circ} \mathrm{C}$ で行ない 2 回繰返した.

3. 直接噴霧法

長沢式噴霧降下装置を用い，直接に各殺虫剤乳凧の $0.5 \%$ （DDT については $5 \%$ ）濃度稀釈溶液を $0.5 \mathrm{cc}$ 
值接に霧噴し時間の経過にともなうノックダウン数およ び $5 \%$ 砂糖水を与えて 24 時間飼育後の致死数を求めた.

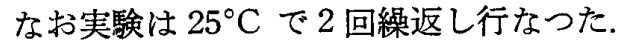

\section{4. 抵抗性簡易測定法}

当研究部で累代飼育した $3 \sim 4$ 世代イエバエ成虫（雌 雄同数）を用いて，イエバエの殺虫剤抵抗性簡易測定法 によつて接触開始後時間の経過にともなうノックダウン 数および 24 時間後の致死数を求めた。なお実験は $25^{\circ} \mathrm{C}$ で行ない各濃度区に 30 頭を用い 2 回繰返した.

\section{5. 浸漬法}

各殺虫剂乳剤の所要濃度稀釈液 $\left(20^{\circ} \mathrm{C}\right)$ 中に麻酔した イエバエ雌成虫 25 頭を金網で蓋をした径 $4 \mathrm{~cm}$ 高さ 5 $\mathrm{cm}$ のガラス円筒中に入れて，3 分間完全に浸漬したの ち，直ちに取り出して濾紙をしいた B̈̈chner の濾斗で 吸引滤過して薬液を吸着除去し，5\%砂糖水を含ませた 脱脂綿を与えて $25^{\circ} \mathrm{C}$ で飼育し，24 時間後の致死数を調 查した. なお実験は 2 回繰返した.

\section{実験結果および考察}

\section{1. 微量滴下法による効力}

微量滴下法によつて得た各殺虫剤の各薬量による致死 率は，変換して薬量-致死率回帰直線として図 1 に示し た. 各回帰直線から Finney の図解法によつて得た $\mathrm{LD}_{50}$ 值は表 1 に示した.

上木田系に対して $\mathrm{LD}_{50}$ 值で示された効力の強さは dichlorvos $>$ naled $>$ fenthion $>$ diazinon $>$ fenitrothion $>$ fenchlorphos $>$ malathion $>$ dieldrin $>$ lindane $>$ trichlorphon $>$ DDT の順で, 中福良系では naled $>$ dichlorvos $>$
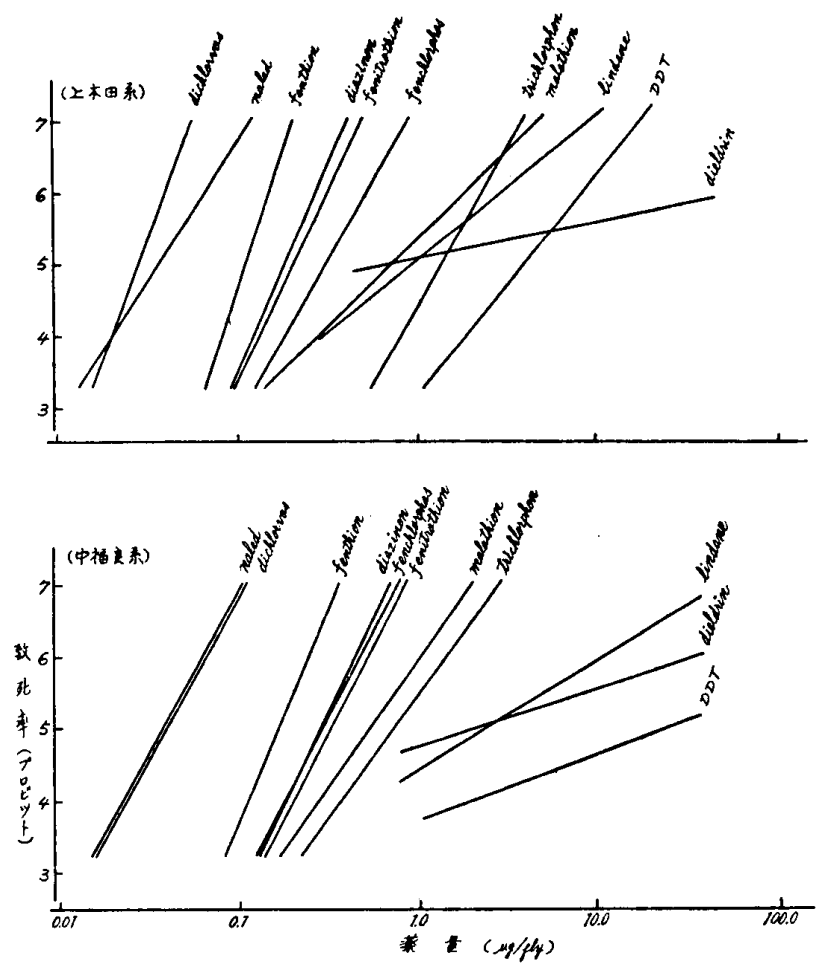

図 1 加治木地区産各系イエバェに対する各種 殺虫剤の微䥣滴下法による薬量一致死率回帰直 線

fenthion $>$ diazinon $>$ fenchlorphos $>$ fenitrothion $>$ malathion $>$ trichlorphon $>$ dieldrin $>$ lindane $>$ DDT の順で あつた。

表 2 は上木田系および中福良系に対する $\mathrm{LD}_{50}$ 值の比 較执よび鈴木ら（1962）の伝研系イエバエについての $\mathrm{LD}_{50}$ 值との比較を示したのである. 中福良系は各塩素 系殺虫剤については，いずれも上木田系よりも大きい值

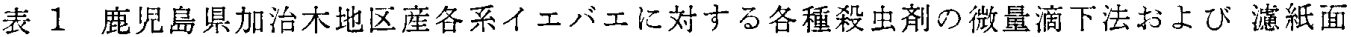
$250 \mathrm{mg} / \mathrm{m}^{2}$ 残渣接触法による $\mathrm{LD}_{50}(\mu \mathrm{g} / \mathrm{fly}), \mathrm{KT}_{50}$ (min.), $\mathrm{LT}_{50}$ (min.)

\begin{tabular}{|c|c|c|c|c|c|c|}
\hline \multirow{2}{*}{ 殺虫剂 } & \multicolumn{3}{|c|}{ 上木田系 } & \multicolumn{3}{|c|}{ 中福 良系 } \\
\hline & $\mathrm{LD}_{50}$ & $\mathrm{KT}_{50}$ & $\mathrm{LT}_{50}$ & $\mathrm{LD}_{50}$ & $\mathrm{KT}_{50}$ & $\mathrm{LT}_{50}$ \\
\hline dichlorvos & 0.0288 & & & 0.0389 & & \\
\hline naled & 0.0363 & 5.8 & 1.6 & 0.0363 & 5.4 & 1.6 \\
\hline diazinon & 0.191 & 24.6 & 9.3 & 0.282 & 22.7 & 15.1 \\
\hline fenchlorphos & 0.316 & 66.8 & 10.0 & 0.288 & 66.1 & 16.0 \\
\hline fenthion & 0.135 & 97.7 & 24.0 & 0.166 & 107.2 & 43.7 \\
\hline fenitrothion & 0.209 & 133.4 & 72.5 & 0.316 & 126.0 & 85.1 \\
\hline trichlorphon & 1.445 & $>251$ & $>251$ & 0.708 & $>251$ & $>251$ \\
\hline malathion & 0.741 & $>251$ & $>251$ & 0.525 & $>251$ & $>251$ \\
\hline dieldrin & 0.759 & $>251$ & $>251$ & 1.738 & $>251$ & $>251$ \\
\hline lindane & 0.955 & 80.0 & $>251$ & 2.089 & 91.2 & $>251$ \\
\hline DDT & 3.981 & $>251^{*}$ & $>251^{*}$ & 21.878 & $>251^{*}$ & $>251^{*}$ \\
\hline
\end{tabular}

* $2500 \mathrm{mg} / \mathrm{m}^{2}$ 
表 2 加治木地区産各采イエバェと伝研采イエバエに詨卞る各種殺虫郕り $\mathrm{LD}_{50}, \mathrm{KT}_{50}, \mathrm{LT}_{50}$ 值の比較 $\mathrm{LD}_{50}(\mu \mathrm{g} / \mathrm{fly})$

\begin{tabular}{|c|c|c|c|c|c|c|}
\hline 殺 虫 剂 & $\begin{array}{l}\text { 上条田系 } \\
\text { (A) }\end{array}$ & $\begin{array}{c}\text { 中福良系 } \\
(\mathrm{B})\end{array}$ & 伝 $\left(\begin{array}{c}\text { 研 } \\
\text { (采) }\end{array}\right.$ & $\mathrm{B} / \mathrm{A}$ & $\mathrm{A} / \mathrm{C}$ & $\mathrm{B} / \mathrm{C}$ \\
\hline dichlorvos & 0.0288 & 0.0389 & 0.031 & 1.4 & 0.9 & 1.3 \\
\hline naled & 0.0363 & 0.0363 & 0.023 & 1.0 & 1.6 & 1.6 \\
\hline diazinon & 0.191 & 0.282 & 0.091 & 1.5 & 2.1 & 3.1 \\
\hline fenchlorphos & 0.316 & 0.288 & 0.16 & 0.9 & 2.0 & 1.8 \\
\hline fenthion & 0.135 & 0.166 & 0.071 & 1.2 & 1.9 & 2.3 \\
\hline fenitrothion & 0.209 & 0.316 & 0.0653 & 1.5 & 3.2 & 4.8 \\
\hline trichlorphon & 1.445 & 0.708 & 0.27 & 0.5 & 5.4 & 2.6 \\
\hline malathion & 0.741 & 0.525 & 0.59 & 0.7 & 1.3 & 0.9 \\
\hline dieldrin & 0.759 & 1.738 & 0.31 & 2.3 & 2.5 & 5.6 \\
\hline lindane & 0.955 & 2.089 & 6.4 & 2.2 & 0.2 & 0.3 \\
\hline DDT & 3.981 & 21.878 & 13.9 & 5.5 & 0.3 & 1.6 \\
\hline
\end{tabular}

$\mathrm{KT}_{50}(\min$.

\begin{tabular}{|c|c|c|c|c|c|c|}
\hline dichorvos & & & $3.76^{1)}$ & & & \\
\hline naled & 5.8 & 5.4 & $11.9^{1)}$ & 1.0 & 0.5 & 0.5 \\
\hline diazinon & 24.6 & 22.7 & $23.9^{1)}$ & 1.1 & 1.0 & 1.0 \\
\hline fenchlorphos & 66.8 & 66.1 & $68.1^{1)}$ & 1.0 & 1.0 & 1.0 \\
\hline fenthion & 97.7 & 107.2 & $95.1^{1)}$ & 1.0 & 1.0 & 1.1 \\
\hline fenitrothion & 133.4 & 126.0 & $101^{12}$ & 0.9 & 1.3 & 1.3 \\
\hline trichlorphon & $>251$ & $>251$ & $360^{2)}$ & & & \\
\hline malathion & $>251$ & $>251$ & $289^{22}$ & & & \\
\hline
\end{tabular}

\begin{tabular}{l|r|r|c|c|c|c} 
dichlorvos & & & $<0.25^{1)}$ & & & \\
naled & 1.6 & 1.6 & $<0.25^{1)}$ & 1.0 & & \\
diazinon & 9.3 & 15.1 & $3.5^{1)}$ & 1.6 & 2.7 & 4.3 \\
fenchlorphos & 10.0 & 16.0 & $22^{12}$ & 1.6 & 0.5 & 0.7 \\
fenthion & 24.0 & 43.7 & $25^{1)}$ & 1.8 & 1.0 & 1.8 \\
fenitrothion & 72.5 & 85.1 & & 1.2 & & \\
trichlorphon & $>251$ & $>251$ & $>360^{2}$ & & & \\
malathion & $>251$ & $>251$ & $>360^{22}$ & & &
\end{tabular}
1) $263 \mathrm{mg} / \mathrm{m}^{2}$
2) $1050 \mathrm{mg} / \mathrm{m}^{2}$

を示した。 または中福良系は fenitrothion および diazinon に対しては上木田系の 1.5 倍, dichlorvos, fenthion についてはわずかに大きい值を, naled, fenchlorphos については同程度の值を, trichlorphon, malathion については小さい值を示した。

上木田系㧍よび中福良系イエバエに対する各殺虫剤の LD50 值を鈴木ら（1962）の DKM 系イエバエについて 求めた $\mathrm{LD}_{50}$ 值に比較すると, 上木田系では, trichlorphon の 5.4 倍を最高に, fenitrothion 3.2 倍, dieldrin 2.5 倍, diazinon 2.1 倍, fenchlorphos 2.0 倍, fenthion 1.9 倍, naled 1.6 倍, malathion 1.3 倍, dichlorvos
0.9 倍, DDT 0.3 倍, lindane 0.2 倍程度の值を示した. 中福良系は, dieldrin の 5.6 倍を最高に, fenitrothion 4.8 倍, diazinon 3.1 倍, trichlorphon 2.6 倍, fenthion 2.3 倍, fenchlorphos 1.8 倍, naled および DDT 1.6 倍, dichlorvos 1.3 倍, malathion 0.9 倍, lindane 0.3 倍程度の值を示した. 図 1 に示した回帰直線の公配から みても上木田系は dieldrin に対して, 中福良系は dieldrin, lindane および DDT に対して抵抗性のイエバエ を含む集団であるとみられた。これらの二つの集団は燐 系殺虫剤に対しても致死薬量からみてレベルの高い強い 集団とみられた。 
衛 生 動 物

1967 年 Vol. 18 No. 4
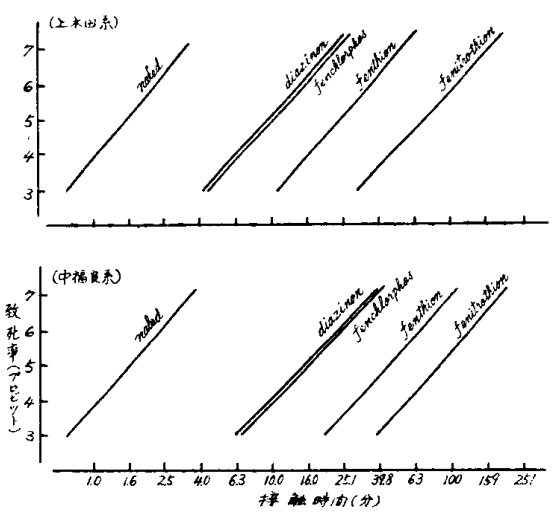

図 3 加治木地区産各系イエバェに対する 各種殺虫剤の濾紙面 $250 \mathrm{mg} / \mathrm{m}^{2}$ 残渣接触 法による時間一致死率回㷌直線

に比較すると二つの 集団ともに diazinon の值が大きく fenchlorphos の值は小さかつた.

4. 濾紙面残渣の残留効力

各日数経過後の濾紙面殺虫剂残渣に，二つの集団のイ エバエを接触させて求めた $\mathrm{KT}_{50}$ および致死率は表 3 に示した. 各殺虫剤の散布後のノックダウン効力は, naled が最も速く, 以下 diazinon, fenchlorphos, fenthion, fenitrothion の順で, 日数の経過にともなつて $\mathrm{KT}_{50}$ 值は大きくなり, その増大する率は fenchlorphos に拈てもつとも大きく，ついで naled, diazinon, fenthion, fenitrothion の順であつた. 致死率において も似たような傾向がみられた. 二つの集団に対する各効 力を比較すると, 全般的に中福良系は, 上木田系より各 殺虫剤に対して，いわゆる強い傾向を示した.

5. 直接噴霧によるノックダウン効力および致死効力 各殺虫剂乳剂の $0.5 \%$ （DDT は $5 \%$ ）濃度稀釈液 $0.5 \mathrm{cc}$ を直接に噴霧した場合の時間の経過にともなうノ ックダウン率および 24 時間後の致死率は表 4 に示した. 噴霧によるノックダウン効力の速さは，二つの集団のい ずれに対しても dichlorvos が最も速く,ついで naled, diazinonの順に速効性で, これらに比較してその他は遅 効性であつた．DDT については $5 \%$ 濃度で用いたが, 比較的に速いノックダウン効力を示した. 致死効力は二 つの集団に対して 同程度の 効力を示し, dichlorvos, naled, diazinon, fenchlorphos, fenthion, fenitrothion がすぐれ, ついで malathion, DDT だ, trichlorphon, dieldrin, lindane はかなり劣つた。

6. 抵抗性簡易测定法による効力

二つのイエバエ集団に対する各種殺虫剤の抵抗性簡易 測定法による稀釈倍率と，処理後 $1 ， 2 ， 4$ 時間後のノ ックダウン率および 24 時間後の 致死率は表 5 , 表 6 に 示した. 表 5 表 6 に示した結果からは，稀釈倍率ーノッ クダウン率, または致死率回帰直線の作図ができないの 
表 3 加治木地区産各系イエバエに対する各種殺虫郕の濾紙面残渣の各日数経過後の $\mathrm{KT}_{50}$ 抒よび致死率

\begin{tabular}{|c|c|c|c|c|c|c|c|c|c|c|}
\hline \multirow{3}{*}{ 殺 虫 剂 } & \multicolumn{10}{|c|}{ 散布後各日数後の $\mathrm{KT}_{50}$ (min.) } \\
\hline & \multicolumn{5}{|c|}{ 上木田系 } & \multicolumn{5}{|c|}{ 中福良采 } \\
\hline & 0 & 5 & 10 & 15 & 20 & 0 & 5 & 10 & 15 & 20 \\
\hline naled & 5.8 & 26.3 & 30.9 & 83.2 & $>316$ & 5.8 & 29.5 & 34.7 & 75.9 & $>316$ \\
\hline diazinon & 24.6 & 56.8 & 57.5 & 95.5 & 231.7 & 22.7 & 75.9 & 69.2 & 229.1 & 260.0 \\
\hline fenchlorphos & 66.8 & 83.2 & 112.2 & 331.1 & 309.1 & 66.1 & 117.4 & 144.6 & $>316$ & $>316$ \\
\hline fenthion & 97.7 & 123.0 & 100.0 & 126.0 & 153.1 & 107.2 & 154.8 & 116.1 & 200.0 & 206.5 \\
\hline fenitrothion & 133.4 & 126.0 & 100.0 & 128.8 & 131.8 & 126.0 & 211.4 & 116.1 & 169.8 & 182.0 \\
\hline
\end{tabular}

\begin{tabular}{|c|c|c|c|c|c|c|c|c|c|c|}
\hline \multirow{3}{*}{ 殺 虫 㧩 } & \multicolumn{10}{|c|}{2 時間接触による致死率 (\%) } \\
\hline & \multicolumn{5}{|c|}{ 上. 木 田 系 } & \multicolumn{5}{|c|}{ 中 福 良 系 } \\
\hline & 0 & 5 & 10 & 15 & 20 & 0 & 5 & 10 & 15 & 20 \\
\hline naled & 100 & 100 & 100 & 95.0 & 0 & 100 & 100 & 100 & 75.0 & 0 \\
\hline diazinon & 100 & 96.3 & 100 & 68.4 & 21.6 & 100 & 85.5 & 93.8 & 35.0 & 5.0 \\
\hline fenchlorphos & 100 & 100 & 83.8 & 12.5 & 10.0 & 100 & 98.8 & 77.5 & 5.9 & 5.0 \\
\hline fenthion & 100 & 100 & 100 & 94.7 & 87.2 & 100 & 82.3 & 100 & 50.0 & 38.5 \\
\hline fenitrothion & 100 & 71.8 & 96.2 & 89.5 & 97.4 & 100 & 47.4 & 97.3 & 61.5 & 62.5 \\
\hline
\end{tabular}

表 4 加治木地区産各系イエバェに対する各種殺虫剂乳剂 $0.5 \%$ 濃度稀釈液 $0.5 \mathrm{cc} の$ 㨁接噴霧によるノックダウン率扔よび致死率

\begin{tabular}{|c|c|c|c|c|c|c|c|c|c|c|c|}
\hline \multirow{3}{*}{ 殺虫剂 } & \multirow{3}{*}{$\begin{array}{l}\text { 稀釈 } \\
\text { 倍率 }\end{array}$} & \multicolumn{10}{|c|}{ 各経過時閒にともなうノックダウン率および24時間後の致死率 } \\
\hline & & \multicolumn{5}{|c|}{ 上杰田 系 } & \multicolumn{5}{|c|}{ 中 福 良 采 } \\
\hline & & 5 分 & 10分 & 20分 & 40 分 & 24 時 & 5 分 & 10 分 & 20分 & 40分 & 24時 \\
\hline dichlorvos $5 \%$ e.c. & 10 & 100 & & & & 100 & 100 & & & & 100 \\
\hline naled $5 \%$ e.c. & 10 & 40.0 & 100 & & & 100 & 45.0 & 97.5 & 100 & & 100 \\
\hline diazinon $5 \%$ e.c. & 10 & 2.5 & 7.5 & 80.0 & 97.5 & 100 & & 2.5 & 82.5 & 97.5 & 100 \\
\hline fenchlorphos $5 \%$ e.c. & 10 & & & & 7.5 & 100 & & & & 25.0 & 100 \\
\hline fenthion $5 \%$ e.c. & 10 & & & 2.5 & 52.5 & 100 & & & & 30.0 & 100 \\
\hline fenitrothion $10 \%$ e.c. & 20 & & & & 27.5 & 100 & & & & 32.5 & 100 \\
\hline trichlorphon $10 \%$ e.c. & 20 & & & & 0 & 68.4 & & & & 0 & 47.4 \\
\hline malathion $20 \%$ e.c. & 40 & & & & 0 & 90.0 & & & & 0 & 97.5 \\
\hline dieldrin $5 \%$ e.c. & 10 & & & & 0 & 38.5 & & & & 2.5 & 35.0 \\
\hline lindane $10 \%$ e.c. & 20 & & & 7.5 & 27.5 & 375 & & & 5.0 & 32.5 & 35.0 \\
\hline DDT 30\% e.c. & $6^{*}$ & 55.0 & 90.0 & 100 & & 95.0 & 30.0 & 80.0 & 100 & & 85.0 \\
\hline
\end{tabular}

\section{* $5 \%$ 濃度}

で， $50 \%$ 程度の効果が推定される $50 \%$ 有効稀釈倍率と して表 7 に示した. もちろんこの方法はフィールドから 採集したイエバエについて行なう目的のものであるが， 室内飼育集団について適用した場合の結果を求めて行な つたものである，各殺虫剤乳片の濃度は，市販製剂を考 慮して同じ倍率で稀釈して行なつた. 上木田系に対する 致死効力は, dichlorvos $5 \%$ e.c. に捺いて最も強く, ついでnaled $5 \%$ e.c. で，これらのつぎは diazinon 5 $\%$ e.c., fenchlorphos $5 \%$ e.c., fenthion $5 \%$ e.c., fenitrothion $10 \%$ e.c., malathion $20 \%$ e.c., lindane $10 \%$ e.c. などであつた. trichlorphon $10 \%$ e.c., dieldrin $5 \%$ e.c. の効力法弱く, DDT $30 \%$ e.c. の効力 は最も弱かつた. ノックダウン効力の速さは dichlorvos $5 \%$ e.c. が最も速く, ついで naled $5 \%$ e.c. で, 以下 
表 5 加治木地区産上木田系イエバエに対する各種殺虫剤の抵抗性簡易測定法による処理後 $1 ， 2 ， 4$ 時閒後のノックダウン率就よび 24 洔間後の致死率

\begin{tabular}{|c|c|c|c|c|c|c|c|c|c|c|c|c|c|c|c|}
\hline \multirow{2}{*}{ 殺 虫 剤 } & \multirow{2}{*}{$\mid \begin{array}{l}\text { 経過 } \\
\text { 時間 }\end{array}$} & \multicolumn{6}{|c|}{ 稀 } & \multicolumn{3}{|c|}{ 倍 } & \multicolumn{5}{|l|}{ 率 } \\
\hline & & 10 & 20 & 50 & 100 & 200 & 400 & 800 & 1600 & 3200 & 6400 & 12800 & 25600 & 512001 & 102400 \\
\hline $\begin{array}{c}\text { dichlorvos } \\
5 \% \text { e.c. }\end{array}$ & $\begin{array}{r}1 \\
2 \\
4 \\
24\end{array}$ & & & & & & & & $\begin{array}{l}100 \\
100 \\
100 \\
100\end{array}$ & $\begin{array}{r}48 \\
100 \\
100 \\
100\end{array}$ & $\begin{array}{r}12 \\
100 \\
100 \\
100\end{array}$ & $\begin{array}{r}12 \\
64 \\
100 \\
100\end{array}$ & $\begin{array}{r}0 \\
16 \\
64 \\
100\end{array}$ & $\begin{array}{r}0 \\
0 \\
8 \\
100\end{array}$ & $\begin{array}{r}0 \\
0 \\
12 \\
60\end{array}$ \\
\hline $\begin{array}{c}\text { naled } \\
5 \% \text { e.c. }\end{array}$ & $\begin{array}{r}1 \\
2 \\
4 \\
24\end{array}$ & & & & & $\begin{array}{l}100 \\
100 \\
100 \\
100\end{array}$ & $\begin{array}{r}16 \\
100 \\
100 \\
100\end{array}$ & $\begin{array}{r}0 \\
32 \\
100 \\
100\end{array}$ & $\begin{array}{r}0 . \\
0 \\
88 \\
100\end{array}$ & $\begin{array}{r}8 \\
8 \\
52 \\
100\end{array}$ & $\begin{array}{r}0 \\
0 \\
12 \\
60\end{array}$ & $\begin{array}{r}0 \\
0 \\
0 \\
44\end{array}$ & $\begin{array}{l}0 \\
0 \\
0 \\
8\end{array}$ & & \\
\hline $\begin{array}{l}\text { diazinon } \\
5 \% \text { e.c. }\end{array}$ & \begin{tabular}{r|}
1 \\
2 \\
4 \\
24
\end{tabular} & & $\begin{array}{l}100 \\
100 \\
100 \\
100\end{array}$ & $\begin{array}{r}44 \\
100 \\
100 \\
100\end{array}$ & $\begin{array}{r}20 \\
90 \\
100 \\
100\end{array}$ & $\begin{array}{r}2 \\
60 \\
84 \\
100\end{array}$ & $\begin{array}{r}2 \\
26 \\
52 \\
90\end{array}$ & $\begin{array}{r}0 \\
14 \\
28 \\
58\end{array}$ & $\begin{array}{r}0 \\
22 \\
30 \\
48\end{array}$ & $\begin{array}{r}0 \\
4 \\
14 \\
26\end{array}$ & $\begin{array}{r}0 \\
8 \\
16 \\
16\end{array}$ & & & & \\
\hline $\begin{array}{c}\text { fenchlorphos } \\
5 \% \text { e.c. }\end{array}$ & $\begin{array}{r}1 \\
2 \\
4 \\
24\end{array}$ & & $\begin{array}{l}100 \\
100 \\
100 \\
100\end{array}$ & $\begin{array}{r}0 \\
18 \\
100 \\
100\end{array}$ & $\begin{array}{r}0 \\
0 \\
84 \\
100\end{array}$ & $\begin{array}{r}0 \\
0 \\
80 \\
100\end{array}$ & $\begin{array}{r}0 \\
0 \\
40 \\
100\end{array}$ & $\begin{array}{r}0 \\
0 \\
12 \\
72 \\
\end{array}$ & $\begin{array}{r}0 \\
0 \\
0 \\
16\end{array}$ & $\begin{array}{r}0 \\
0 \\
0 \\
12\end{array}$ & & & & & \\
\hline $\begin{array}{l}\text { fenthion } \\
5 \% \text { e.c. }\end{array}$ & \begin{tabular}{r|r|}
1 \\
2 \\
4 \\
24
\end{tabular} & & $\begin{array}{l}100 \\
100 \\
100 \\
100\end{array}$ & $\begin{array}{r}20 \\
100 \\
100 \\
100\end{array}$ & $\begin{array}{r}0 \\
0 \\
92 \\
100\end{array}$ & $\begin{array}{r}0 \\
0 \\
16 \\
100\end{array}$ & $\begin{array}{r}0 \\
0 \\
4 \\
100\end{array}$ & $\begin{array}{r}0 \\
0 \\
0 \\
52\end{array}$ & $\begin{array}{r}0 \\
0 \\
0 \\
32\end{array}$ & $\begin{array}{r}0 \\
0 \\
0 \\
16\end{array}$ & & & & & \\
\hline $\begin{array}{c}\text { fenitrothion } \\
10 \% \text { e.c. }\end{array}$ & $\begin{array}{r}1 \\
2 \\
4 \\
24\end{array}$ & & $\begin{array}{l}100 \\
100 \\
100 \\
100 \\
\end{array}$ & $\begin{array}{r}0 \\
38 \\
100 \\
100 \\
\end{array}$ & $\begin{array}{r}2 \\
26 \\
98 \\
100\end{array}$ & $\begin{array}{r}0 \\
2 \\
60 \\
100\end{array}$ & $\begin{array}{r}0 \\
4 \\
12 \\
100\end{array}$ & $\begin{array}{r}0 \\
4 \\
8 \\
80\end{array}$ & $\begin{array}{r}0 \\
0 \\
4 \\
30\end{array}$ & $\begin{array}{r}0 \\
2 \\
2 \\
32\end{array}$ & & & & & \\
\hline $\begin{array}{c}\text { trichlorphon } \\
10 \% \text { e.c. }\end{array}$ & $\begin{array}{r}1 \\
2 \\
4 \\
24\end{array}$ & & & & & $\begin{array}{l}100 \\
100 \\
100 \\
100\end{array}$ & $\begin{array}{r}0 \\
4 \\
8 \\
40\end{array}$ & $\begin{array}{r}0 \\
0 \\
0 \\
20\end{array}$ & $\begin{array}{r}0 \\
0 \\
4 \\
12\end{array}$ & & & & & & \\
\hline $\begin{array}{l}\text { malathion } \\
20 \% \text { e.c. }\end{array}$ & \begin{tabular}{r|}
1 \\
2 \\
4 \\
24
\end{tabular} & & $\begin{array}{l}100 \\
100 \\
100 \\
100\end{array}$ & $\begin{array}{r}100 \\
16 \\
96 \\
100\end{array}$ & $\begin{array}{r}8 \\
44 \\
100 \\
100\end{array}$ & $\begin{array}{r}0 \\
0 \\
60 \\
100\end{array}$ & $\begin{array}{r}0 \\
0 \\
60 \\
100\end{array}$ & \begin{tabular}{r|}
0 \\
0 \\
25 \\
96
\end{tabular} & $\begin{array}{r}0 \\
0 \\
0 \\
20\end{array}$ & $\begin{array}{l}0 \\
0 \\
0 \\
8\end{array}$ & & & & & \\
\hline $\begin{array}{l}\text { dieldrin } \\
5 \% \text { e.c. }\end{array}$ & $\begin{array}{r}1 \\
2 \\
4 \\
24\end{array}$ & & & $\begin{array}{l}100 \\
100 \\
100 \\
100\end{array}$ & $\begin{array}{r}100 \\
84 \\
40 \\
92\end{array}$ & $\begin{array}{r}0 \\
8 \\
4 \\
40\end{array}$ & $\begin{array}{r}0 \\
0 \\
4 \\
52\end{array}$ & & & & & & & & \\
\hline $\begin{array}{l}\text { lindane } \\
10 \% \text { e.c. }\end{array}$ & \begin{tabular}{r|}
1 \\
2 \\
4 \\
24
\end{tabular} & & $\begin{array}{l}100 \\
100 \\
100 \\
100\end{array}$ & $\begin{array}{r}36 \\
52 \\
92 \\
100\end{array}$ & $\begin{array}{r}12 \\
60 \\
56 \\
100\end{array}$ & \begin{tabular}{r|}
6 \\
26 \\
54 \\
94
\end{tabular} & $\begin{array}{r}4 \\
20 \\
40 \\
80\end{array}$ & $\begin{array}{r}0 \\
8 \\
44 \\
76\end{array}$ & $\begin{array}{r}0 \\
0 \\
32 \\
48\end{array}$ & & & & & & \\
\hline $\begin{array}{l}\text { DDT } \\
30 \% \text { e.c. }\end{array}$ & $\begin{array}{r}1 \\
2 \\
4 \\
24\end{array}$ & $\begin{array}{l}100 \\
100 \\
100 \\
100\end{array}$ & $\begin{array}{r}100 \\
100 \\
80 \\
84\end{array}$ & $\begin{array}{l}30 \\
88 \\
84 \\
60\end{array}$ & $\begin{array}{l}20 \\
56 \\
44 \\
36\end{array}$ & & & & & & & & & & \\
\hline
\end{tabular}

diazinon $5 \%$ e.c., malathion $20 \%$ e.c. で, その他は 比較的に遅效性であつた．中福良系に対する致死効力は dichlorvos $5 \%$ e.c. が最も強く,ついで naled $5 \%$ e.c., malathion $20 \%$ e.c. で, これらのつぎは diazinon $5 \%$ e.c., fenchlorphos $5 \%$ e.c., fenthion $5 \%$ e.c., feni- trothion $10 \%$ e.c. などであった. lindane $10 \%$ e.c., trichlorphon $10 \%$ e.c. はこれらに比較して効力は弱く, dieldrin $5 \%$ e.c., DDT $30 \%$ e.c. の効力は最も弱か つた. 二つの集団に対する効果を比較すると，中福良系 は上木田系に比較して各殺虫片に対して約 2 倍程度の強 
表 6 加治木地区産中福良系イエバエに対寸る各種殺虫剂の抵抗性簡易測定法による処理後 $1 ， 2 ， 4$ 時䦩後りノックダウン率执よで 24 時間後の致死率

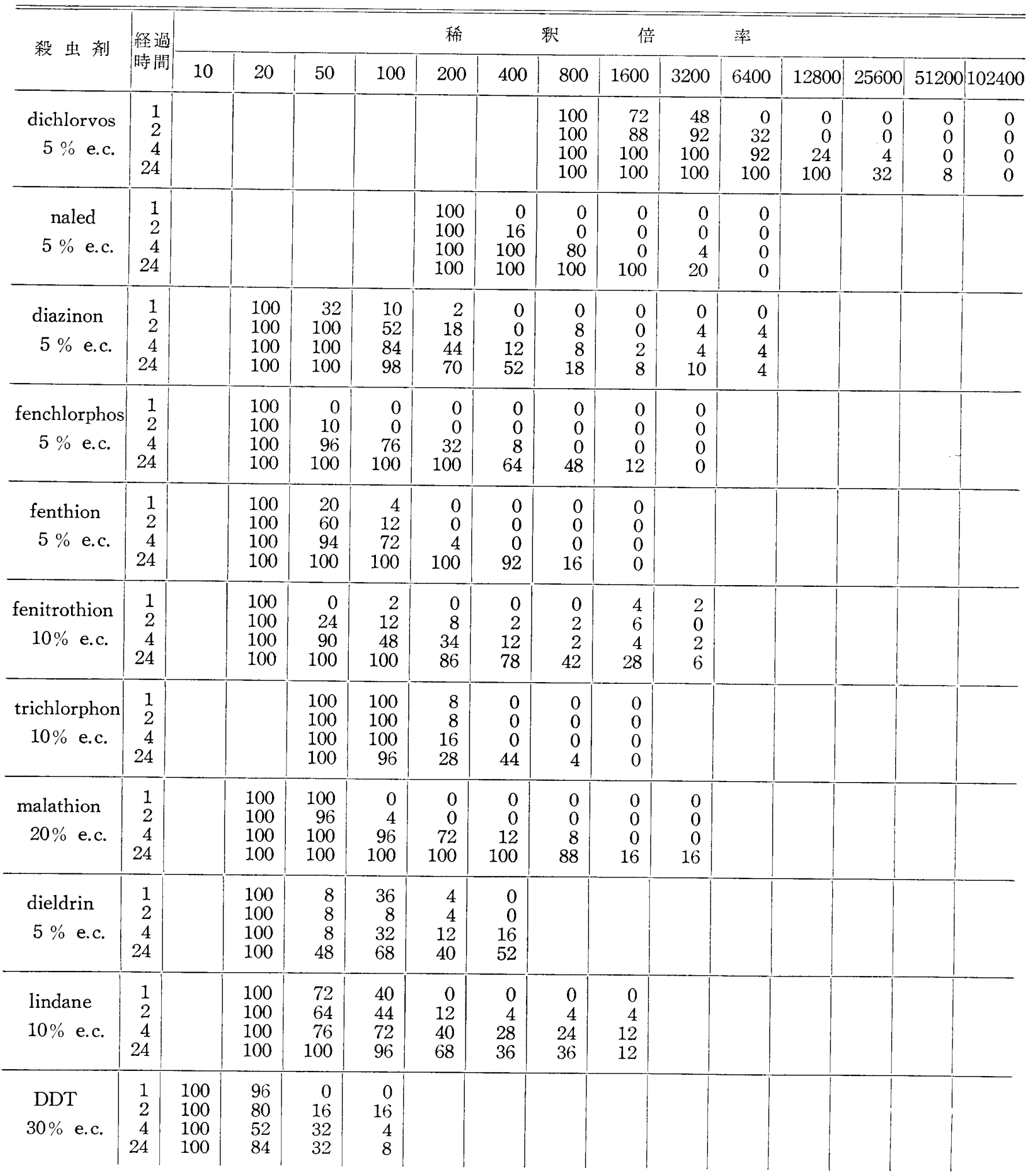

さを示した。

\section{7. 浸漬法による効力}

各系イエバエに対する各殺虫剤乳剂の各稀釈倍率によ る致死率は表 8 に，稀釈倍率一致死率回帰直線注図 4 に， 各回帰直線から求めた $50 \%$ 致死稀釈倍率拉よび 各殺虫
剂原体についての $\mathrm{LC}_{50}$ 值は表 9 に示した.

二つの集団に 対する致死効力を 各乳剤の $50 \%$ 致死稀 釈倍率で比較すると，各系ともに， fenthion $5 \%$ e.c. が最もすぐれ，最も大きな稀釈倍率を示し，ついで fenitrothion $10 \%$ e.c., diazinon $5 \%$ e.c., malathion 
表 7 加治木地区産各采イエバエに対寺る各種殺虫剤の抵抗性䉮易测定法による50\%有効稀釈倍率

\begin{tabular}{|c|c|c|c|c|c|c|c|c|}
\hline \multirow{3}{*}{ 殺虫凨 } & \multirow{2}{*}{\multicolumn{4}{|c|}{50}} & 勫 稀 & 率 & & \\
\hline & & & & & \multicolumn{4}{|c|}{ 中福 良系 } \\
\hline & 1 時間後 & 2 & 4 & 24 & 1 & 2 & 4 & 24 \\
\hline dichlorvos $5 \%$ e.c. & $1600 \sim 3200$ & $\begin{array}{r}12800 \sim \\
25600\end{array}$ & $\begin{array}{r}25600 \sim \\
51200\end{array}$ & $\begin{array}{r}102400 \sim \\
204800\end{array}$ & $1600 \sim 3200$ & $3200 \sim 6400$ & $\begin{array}{l}6400 \sim \\
12800\end{array}$ & $\begin{array}{l}12800 \sim \\
25600\end{array}$ \\
\hline naled $5 \%$ e.c. & $200 \sim 400$ & $400 \sim 800$ & $3200 \sim$ & $\begin{array}{l}6400 \sim \\
12800\end{array}$ & $200 \sim 400$ & $200 \sim 400$ & $800 \sim 1600$ & $1600 \sim 3200$ \\
\hline diazinon $5 \%$ e.c. & $20 \sim 50$ & $200 \sim 400$ & $400 \sim 800$ & $800 \sim 1600$ & $20 \sim 50$ & $100 \sim 200$ & $100 \sim 200$ & $400 \sim 800$ \\
\hline fenchlorphos $5 \%$ e.c. & $20 \sim 50$ & $20 \sim 50$ & $200 \sim 400$ & $800 \sim 1600$ & $20 \sim 50$ & $20 \sim 50$ & $100 \sim 200$ & $400 \sim 800$ \\
\hline fenthion $5 \%$ e.c. & $20 \sim 50$ & $50 \sim 100$ & $100 \sim 200$ & $800 \sim 1600$ & $20 \sim 50$ & $50 \sim 100$ & $100 \sim 200$ & $400 \sim 800$ \\
\hline fenitrothion $10 \%$ e.c. & $20 \sim 50$ & $20 \sim 50$ & $200 \sim 400$ & $800 \sim 1600$ & $20 \sim 50$ & $20 \sim 50$ & $50 \sim 100$ & $400 \sim 800$ \\
\hline trichlorphon $10 \%$ e.c. & $200 \sim 400$ & $200 \sim 400$ & $200 \sim 400$ & $200 \sim 400$ & $100 \sim 200$ & $100 \sim 200$ & $100 \sim 200$ & $100 \sim 200$ \\
\hline malathion $20 \%$ e.c. & $50 \sim 100$ & $20 \sim 50$ & $400 \sim 800$ & $800 \sim 1600$ & $50 \sim 100$ & $50 \sim 100$ & $200 \sim 400$ & $800 \sim 1600$ \\
\hline dieldrin $5 \%$ e.c. & $100 \sim 200$ & $100 \sim 200$ & $50 \sim 100$ & $100 \sim 200$ & $20 \sim 50$ & $20 \sim 50$ & $20 \sim 50$ & $20 \sim 50$ \\
\hline lindane $10 \%$ e.c. & $20 \sim 50$ & $100 \sim 200$ & $200 \sim 400$ & $800 \sim 1600$ & $50 \sim 100$ & $50 \sim 100$ & $100 \sim 200$ & $200 \sim 400$ \\
\hline DDT $30 \%$ e.c. & $20 \sim 50$ & $100 \sim 200$ & $50 \sim 100$ & $50 \sim 100$ & $20 \sim 50$ & $20 \sim 50$ & $20 \sim 50$ & $20 \sim 50$ \\
\hline
\end{tabular}
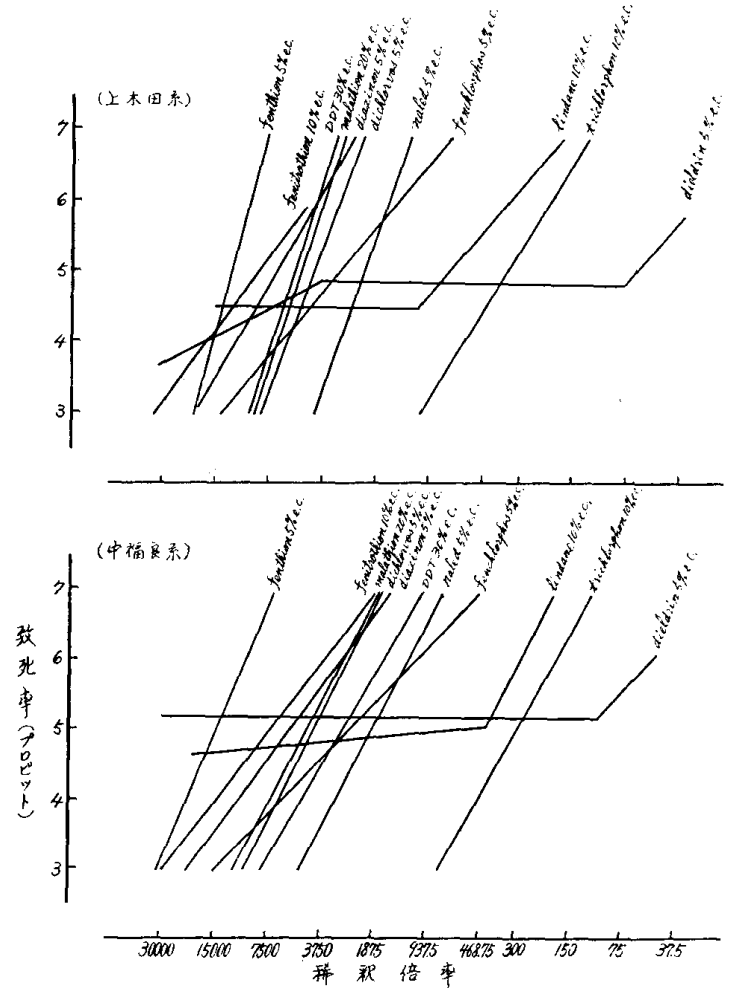

図4 加治木地区産各系イエバエに対する各種 殺虫剂乳剂の浸漬法による稀釈倍率一致死率回 㷌直線

$20 \%$ e.c., DDT $30 \%$ e.c., dichlorvos $5 \%$ e.c., fenchlorphos $5 \%$ e.c., naled $5 \%$ e.c. などで, trichlorphon $10 \%$ e.c., lindane $10 \%$ e.c., dieldrin $5 \%$ e.c. などの効力は比較的に小さかつた。

表 8 抢よび図 4 に示したように，各系ともに dieldrin および lindane に対しては約 $50 \%$ 前後の割合で，いわ
ゆる，これらの殺虫剤に対して感受性の個体と抵抗性の 個体とが混在する集団とみられた。

ここに用いた二つの集団に対する浸漬法による致死効 力は, 各殺虫凰について各系ともに同様な 結果を示し た.

各殺虫剤原体についての $\mathrm{LC}_{50}$ 值は fenthion におい て最小で, ついで diazinon, dichlorvos, fenitrothion, fenchlorphos, naled, malathion などであつた. trichlorphon, lindane, dieldrin, DDT の効力注比較的に劣つ ていた.

これらの結果は大串ら（1966）による殺虫片のアセ卜 ンまたはエタノール溶液の稀釈による結果に比較して, LC 50 値が全般的に大きく，また fenchlorphos による 効力が劣つているが, trichlorphon, lindane, dieldrin, DDT などの効力については同様にかなり効力が低いこ とを示した.

\section{綜合考察}

微量滴下法による効力の評価は，各殺虫剤の基礎的な 効力として，また他の殺虫睮との相互的な比較，または 同一の殺虫剤での異る集団に対する感受性ないし抵抗性 の測定などに有用な方法であり，この微量滴下法による 結果をもとにして，さらに適用条件を考虑して，他の試 験方法によつて各殺虫剂の特性および実用性を検討す心゙ きものであると考えられる、殺虫剤残渣面接触法による 効力比較は, 残渣面接触を目的とする適用方法に適して おり，ノックダウン効力によつて比較することができる が，供試昆虫集団の抵抗性の発達によるノックダウン後 


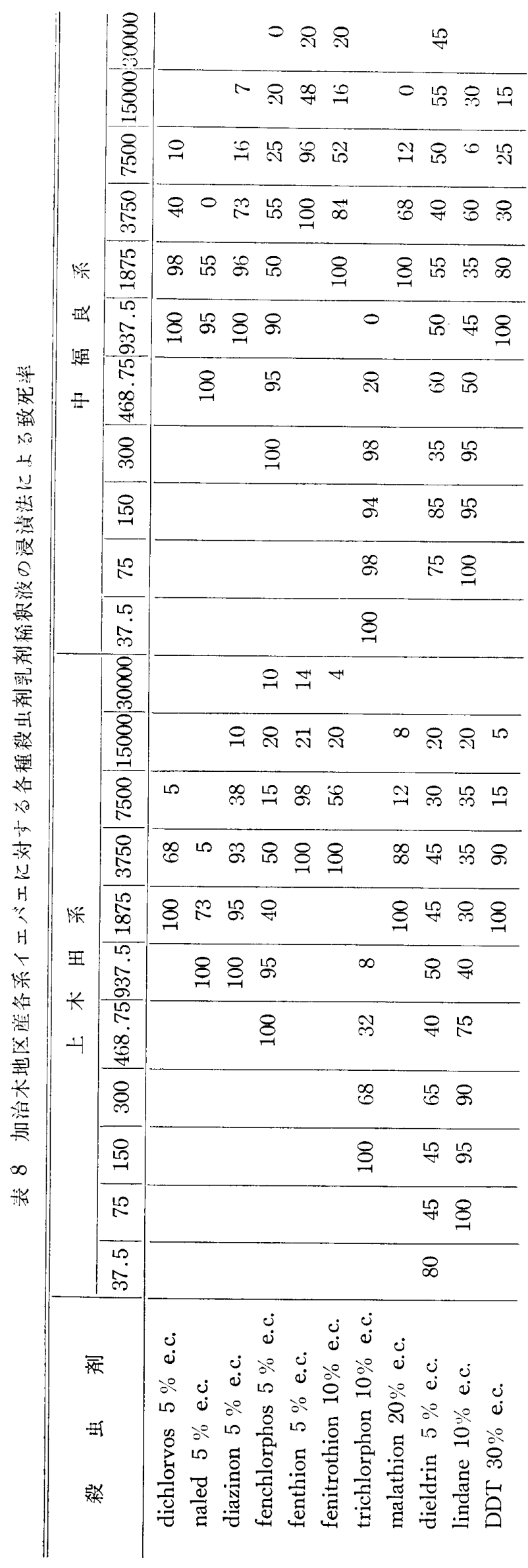

の蘇生回復現象を考慮すると致死接触時間をもつて，効 力を比較するほうが適確である. 残留効力については, 実験条件，環境条件などによる变動が激しいので，実験 条件の規制と実験の反復回数，供試虫数などを考虑する 必要がある。

殺虫剤抵抗性簡易測定法による効力は，イエバエ集団 の抵抗性の測定と殺虫剤の効力比較に適用できるが，こ の方法は抵抗性を測定する一つの予備試験的なものであ るので, 必ず次の段階として微量滴下法または適確な他 の方法によって検討し考察することが必要である. また 実際面に扔ける各殺虫版の実用性を検討する面にも適用 でき，この測定法による結果は慎重に取扱うべきであ る.

浸漬法による比較効力は, 他の実験方法による評価と はかなり異つて扔り,この結果のもつ意義の検討は今後 にゆずるが，この方法による実験結果にみられるよう に, 自然集団にお打可殺虫剤抵抗性の遺伝的構成の解析 および殺虫剤による缽汰方法として利用しうるものとみ とめられる。

加治木地区産上木田系およで中福良系イエバエに対す る各殺虫剤の効力は, 残渣面接触法では naled, diazinon, fenchlorphos, fenthion, fenitrothion などがすぐ れ，噴霧法では dichlorvos, naled, diazinon, fenchlorphos, fenthion, fenitrothion などがすぐれ, 各効力の速 さは dichlorvos, naled, diazinon などが速效性で，こ れらの各殺虫剂はそれぞれの適用目的に有用なものとみ とめられた。

\section{まとめ}

1966 年 11 月鹿児島県加治木町上木田部落掞よび中福 良部落より採集したイエバエを実験室内で累代飼育し て, 11 種の殺虫扸について, 微量滴下法, 残渣面接触 法，噴霧法，抵抗性簡易測定法，浸漬法などによって各 殺虫剂の効力を比較検討した.

残渣面接触による効力法 naled, diazinon, fenchlorphos, fenthion, fenitrothion などがすぐれ，噴霧による 効力は dichlorvos, naled, diazinon, fenchlorphos, fenthion, fenitrothion などがすぐれ，各効力の速さは dichlorvos, naled, diazinon などが速効性で，これらの 各殺虫剤はそれぞれの適用目的に有用であるとみとめら れた.

また，浸漬法による結果から，これらの各イエバエ集 団は dieldrin おょび lindane に対して感受性の個体と 抵抗性の個体が混在している集団とみられた.

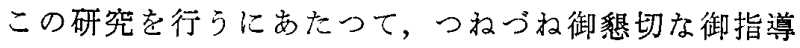
をいただいている東京大学伝染病研究所佐々学教授, 日 
表 9 加治木地区産各系イエバェに対する各種殺虫剤乳刜の浸漬法による $50 \%$ 致死稀釈倍率および $\mathrm{LC}_{50}$ (ppm)

\begin{tabular}{|c|c|c|c|c|}
\hline \multirow{2}{*}{ 殺虫剂 } & \multicolumn{2}{|c|}{ 上木田系 } & \multicolumn{2}{|c|}{ 中福 良 系 } \\
\hline & $\begin{array}{l}50 \% \text { 致死 } \\
\text { 稀釈倍率 }\end{array}$ & $\begin{array}{l}\text { 殺虫剂原体の } \\
\mathrm{LC}_{50}(\mathrm{ppm}) \\
\end{array}$ & $\begin{array}{l}50 \% \text { 致死 } \\
\text { 稀釈倍率 }\end{array}$ & $\begin{array}{l}\text { 殺虫浏原体の } \\
\mathrm{LC}_{50}(\mathrm{ppm})\end{array}$ \\
\hline dichlorvos $5 \%$ e.c. & 4365 & 11.5 & 4365 & 11.5 \\
\hline naled $5 \%$ e.c. & 2291 & 21.8 & 1995 & 25.1 \\
\hline diazinon $5 \%$ e.c. & 7080 & 7.1 & 5623 & 8.9 \\
\hline fenchlorphos $5 \%$ e.c. & 3311 & 15.1 & 2754 & 18.2 \\
\hline fenthion $5 \%$ e.c. & 12302 & 4.1 & 14454 & 3.5 \\
\hline fenitrothion $5 \%$ e.c. & 8318 & 12.0 & 7413 & 13.5 \\
\hline trichlorphon $10 \%$ e.c. & 398 & 251.3 & 316 & 316.5 \\
\hline malathion $20 \%$ e.c. & 5248 & 38.1 & 4571 & 43.8 \\
\hline dieldrin $5 \%$ e.c. & $\begin{array}{c}45 \% \\
75 \sim 3750\end{array}$ & $\begin{array}{c}\mathrm{LC}_{45} \\
13.3 \sim 666.7\end{array}$ & $\begin{array}{c}56 \% \\
105 \sim 3000\end{array}$ & $\begin{array}{c}\mathrm{LC}_{56} \\
16.7 \sim 476.2\end{array}$ \\
\hline lindane $10 \%$ e.c. & $\begin{array}{c}31 \% \\
1047 \sim 15000\end{array}$ & $\begin{array}{l}\mathrm{LC}_{31} \\
6.7 \sim 95.5\end{array}$ & $\begin{array}{c}30 \sim 50 \% \\
469 \sim 15000\end{array}$ & $\begin{array}{c}\mathrm{LC}_{30-50} \\
6.7 \sim 213.2\end{array}$ \\
\hline DDT $30 \%$ e.c. & 5495 & 546.0 & 2884 & 1040.2 \\
\hline
\end{tabular}

本環境衛生センタ一第二事業部長鈴木猛博士に 媣く感 謝しイェバェの採集に御尽力いただいた鹿児島県衛生 部高田真也氏，加治木保健所長中原静彦氏，同衛生課長 上別府酸氏，その他の方々に御礼申し上げます。

\section{文献}

1）日本衛生動物学会殺虫剂研究班（1963）：殺虫剂 研究班のしおり。11:5-7. -2) 長沢純夫 (1953)： “pyrethrins” I IIのイエバェの成虫落下仰転 せしめる効力の比較. 殺虫剂の生物試験にかんする 研究. 第 30 報. 防虫科学, 18(4) : 183-192. -3) 大串晃治・德満繁 ・岩田登美子 (1966)：浸漬法に よるイエバェ抢よびチャバネゴキブリに対する殺虫 郕の効力。衛生動物，17(3) : 209-213.-4) Suzuki, T., Ikeshoji, T.\& Shirai, M. (1958) : Insecticide resistance in several strains of housefly in Japan. Japan. J. Exp. Med., 28(6) : 395-404. -5) 鈴木 猛・水谷澄 (1962)：新殺虫剤 Sumithion のイェバ エおよびアカイエカに対古る効力. 衛生動物, 13 （4）：302-305，-6）鈴木猛・松永秀子（1962）：各 種有機燐剤のイエバェに対する殺虫効力比較. 衛生 動物，13(1)：44-56. -7) 鈴木猛・水谷澄 - 海野 登久子・松永秀子 (1964)：アカイエカ幼虫自然集 団の dieldrin 抵抗性の解析. 衛生動物, 15(3) : 166173.

\section{Summary}

Laboratory tests on the effects of eleven insecticides against two colonies of the housefly, Musca domestica vicina Macquart collected from Kajiki of Kagoshima Prefecture in November of 1966, were carried out by topical application method, contact method to insecticide residues, spraying method and dipping method in laboratory.

Insecticides used were as follows: dichlorvos, naled, diazinon, fenchlorphos, fenthion, fenitrothion, trichlorphon, malathion, dieldrin, lindane and DDT.

Mortality after contact to the residues was higher in naled, diazinon, fenchlorphos, fenthion and fenitrothion. The others were less effective. Mortality in the spray tests was higher in dichlorvos, naled, diazinon, fenchlorphos, fenthion and fenitrothion; and the others were less effective. In contact tests and spray tests, dichlorvos, naled and diazinon were more rapid in knockdown than the others.

Both colonies of the housefly used were presumed to be the mixture of susceptible and resistant populations to dieldrin and lindane after the results of dipping tests. 